\title{
PAVILION ARCHITECTURE - A MODEL OR EPHEMERA? TOWARDS AN ELEMENTARITY OF MEANINGS
}

\section{ARCHITEKTURA PAWILONOWA - WZORZEC CZY EFEMERYDA? W STRONĘ ELEMENTARNOŚCI ZNACZEŃ}

\author{
Marcin Charciarek \\ Dr hab. inż. arch., Prof. Politechniki Krakowskiej \\ Author's Orcid number: 0000-0001-9634-3902 \\ Politechnika Krakowska \\ Wydział Architektury \\ Katedra Projektowania Architektonicznego A-6
}

\begin{abstract}
Undoubtedly, since the beginning of the 20th century, pavilion architecture has become the architect's manifesto and destroys the sense of the history of architecture, which says that architecture is subject to one aesthetic idea, forms and materials.. This paradox of the new, 'impermanent' paradigm is based on constant assessment and discussion in pursuit of an answer to the question about what architecture is in the present day. It may seem that some it s every answer to the originality of form, while to others, a pursuit of meanings in the simplest geometries, in the elementarity of the meanings of architectural space.
\end{abstract}

Key words: elementary architecture, pavilion architecture, permanence of meanings.

\section{STRESZCZENIE}

Bez wątpienia architektura pawilonowa od poczatku XX wieku stała manifestem architekta i burzy sens historii architektury mówiącej o tym, że architektura podlega trwaniu jednej idei estetycznej, form, materiałów. Ów paradoks nowego „nietrwałego” paradygmatu podlega ciągłej ocenie i dyskusji w ramach poszukiwania odpowiedzi na pytanie - co to jest architektura we współczesności? Jak sie wydaje - dla jednych, jest każdą odpowiedzią na temat oryginalnosci formy - dla innych, poszukiwaniem znaczeń w najprostszych geometriach i w elementarności znaczeń przestrzeni architektonicznej.

Słowa kluczowe: architektura elementarna, architektura pawilonowa, trwałość znaczeń. 


\section{GOAL AND METHOD}

The aim of the article is to show, by means of selected examples, the transformation of the pardigm of the durability of contemporary architecture that took place at the turn of the 20th and 21st centuries. On the one hand, the example of pavilion architecture has become a model for understanding the meanings of temporality and looking for current needs and functions in the pavilion's function, and on the other hand - pavilion forms are responsible for creating new directions and ideas for contemporary architecture. Undoubtedly, one of the essential styles is the orientation of the temporary architecture towards primary elementary references.

A method of representing patterns (from the past and the present) important for the present, synthesizing the problem of temporal architecture, was adopted.

\section{INTRODUCTION}

Descriptions of the world of twenty-first-century architecture have ceased to define the sense of permanence and continued existence of architecture. It is even being proclaimed that architecture not only disappears, but that its continued existence is being abandoned, in addition to the death of the place and context - and that all efforts to give them meaning are in vain. In a global world, its individual, unique character becomes lost and the historical layer of the memory embedded in it likewise disappears. In this perspective, asking the question about the permanence or impermanence of architecture appears to be pointless. According to contemporaries, a portion of architecture in an era of unstable culture, economic crises and climate change follows the path laid out by Archigram, Coop Himmelb(l)au, Buckminster Fuller - or in the present, accounting for the cardboard works by Shigeru Ban, the wooden structures of Pezo von Ellrichshausen or the Parisian follies by Bernard Tschumi. Some designers are of the opinion that architecture denotes a confinement to building the smallest fragments of our biosphere - out of anything, for anyone, wherever and without giving thought for how long - it is about the building becoming an example of a turn towards the most fundamental manner of understanding architecture - towards its elementary sources.

The phenomenon of pavilion architecture attests to this. It is a deliberate manifesto of creating a temporary and alternative object (apart from beauty, durability and utility), which is to primarily speak through an original (yet short-lived) design of form and matter. Utility in this form of 'sculpture' is merely a pretext for creating an exceptional effect of architecture - often without a common principle, an acknowledged rule, a reference to a specific theory. Those who want proof of the ultimate breaking down of the Vitruvian Triad should see the artefacts of the yearly construction of the Serpentine Pavilion at the Kensington Gardens or pavilions for EXPO world fairs, events which are as 'fleeting' as the expressiveness of the individual aspirations of architects.

The temporariness of such an ephemera does not mean that the idea of architecture as such is disappearing. It continues to exist, for as long as the memory of an edifice lasts - for as long as the words, thoughts and sketches, a fragment of material or a colour or texture left on it is understandable. The Barcelona Pavilion by Ludwig Mies van der Rohe, rebuilt after many years, leaves no doubt that in the end, the value of art (even of the most fragile kind) goes beyond the individual, beyond their time and the conditions of their existence - as confirmed by the words of Heraclitus: 'nothing is, but everything is becoming'.

The idea of pavilion architecture overlaps with the history of modern architecture. Since the start of the twentieth century, the phenomenon of pavilion architecture has been providing a pretext to begin discussing architecture in the category of novelty and originality. Novelty was to manifest itself through a lack of any sort of references, while originality - through the unobviousness of form. World fairs also denote the beginning of design of the appearance of something that can be architecture, a bridge, a piece of furniture or a machine. The words of Hans Hollein from 1969 that 'everything is architecture' summarise the entirety of the phenomenon that links architecture with everything that can become it regardless of function, atypical structure or a shape not seen among buildings. 
Today, the price for establishing the matter this way is impermanence and temporality. The pavilion that is more novel or solves currently relevant matters (be they formal, societal, structural) becomes an original object and often remains in the history of architecture's contemporaneity as a 'primary object'. The pavilion, which is small and pursues the essence of the matter in its expression and meaning, has become that which is the most important in current postulates of contemporaneity in its synthesis.

The Eiffel Tower, built as an entrance gate for the 1889 World's Fair in Paris, is an example that begins the history of pavilion architecture as a temporary object that nevertheless continues to exist through time and has survived. The Tower continues to remain a symbol of the city and the mostoften visited pavilion in the world.

\section{PERMANENCE OF MODERNITY'S PATTERNS}

Pavilion architecture - beginning with the London Crystal Palace by Joseph Paxton (1851) - has become a type of authorial, political, ideological manifesto, which always displays new technology, culture and aesthetics. Since that moment, the pavilion has become a type of architectural model built to a scale of $1: 1$ - it is a narrative without words and writings, displaying the essence of architecture using the most expressive, formally condensed means. Oftentimes, pavilions are an introduction to grand and significant works that discovered new definitions of architectural space. To Modernism, the International Exhibition of Modern Decorative and Industrial Arts that took place in 1925 was one such breaking point, where Le Corbusier presented the ideas of L'Esprit Nouveau (fig.1a) for the first time, using a white, purist building.

The edifice, which included a concept of a model residential space, became a foreshadowing of a house based on the free plan and that would later go on to realise the five points of modern architecture in Poissy and Weissenhof three years later. The USSR pavilion by Konstantin Melnikov was another significant event (fig. 1b). It gave rise to Constructivism in the architecture of the Soviet Union (and later in all of Western Europe), via its original approach to the dependency between the justification and aesthetic of the structural system and its functional assumptions. The structure of the USSR pavilion, revealed outside for the first time (in this case it was made from steel) plays a superior role to utility - just as pure avant-garde formalism of this work foreshadowed everything that was to happen in architecture between post-war Brutalism and later Deconstructivism. The phenomenon of Melnikov's pavilion also anticipated a transformation of the architectural profession in the pursuit of logical, pure and technical shapes for purely fictitious purposes.

The third pillar of model of contemporary Modernist architecture is undoubtedly the German pavilion in Barcelona by Mies van der Rohe (fig. 1c), built for a World's Fair in 1929. The building is a demonstration of the future Modernist shaping of space, which utilised the principle of a fully open, asymmetrical plan, in which there was no clear division between the exterior and the interior. For the first time,, the walls became freed from their structural purpose, only becoming a partition subjected solely to building composition and became a visualisation of space, which the architect would go on to reference in all of his later residential and public designs. Mies van der Rohe BarceIona work is also a pillar of future Rationalist architecture and encompassing Minimalist trends. The reconstruction of the pavilion in 1986 by Spanish architects Cristiano Circi, Fernando Ramos and Ignasi de Solà-Morales i Rubió, confirms the fact of the continued existence of Mies van der Rohe's architecture and the undeniable will of the continuous documenting of his role in contemporary architecture.

\section{PATTERNS OF EVERY IDEA}

Ephemeral architecture has existed since the beginning of our history. However, the fact that an architecture of lesser and greater permanence can exist has never attracted our attention or interest. Even the primitive shelter of Abbot Laugier, mythical in its architectural significance, was not a reflection on the sense of the continued existence of rational timber architecture apart from its purely formal and source-related significance. And yet, when humans moved from a nomadic to 
a settled lifestyle, they began to prize stability and durability of the space in which they existed. Since that time, houses in a settlement were intended to provide a comfortable place to spend all seasons of the year in one place. Their durability and permanence, dependent on nature, has remained a concept that is fundamental to understand architecture as human creation conveyed by enhancing culture within a given system. Durability and permanence as systematised in the canons of (Vitruvian) Western European civilisation, is also a manner of thinking about architecture as a work of art (artificio) - and thus a part of heritage and community. It did not distinguish between the durability of matter and the permanence of the idea. This was based on a clear conviction that continuity in architecture applies primarily to the patterns of monumental res privata (seats of power, religious buildings, palaces), which was distinguished from the impermanent res publica (common housing or production architecture). This understanding of architecture was reflected in building materials, the approach to understanding how they should be used semantically and about the goal of their use.
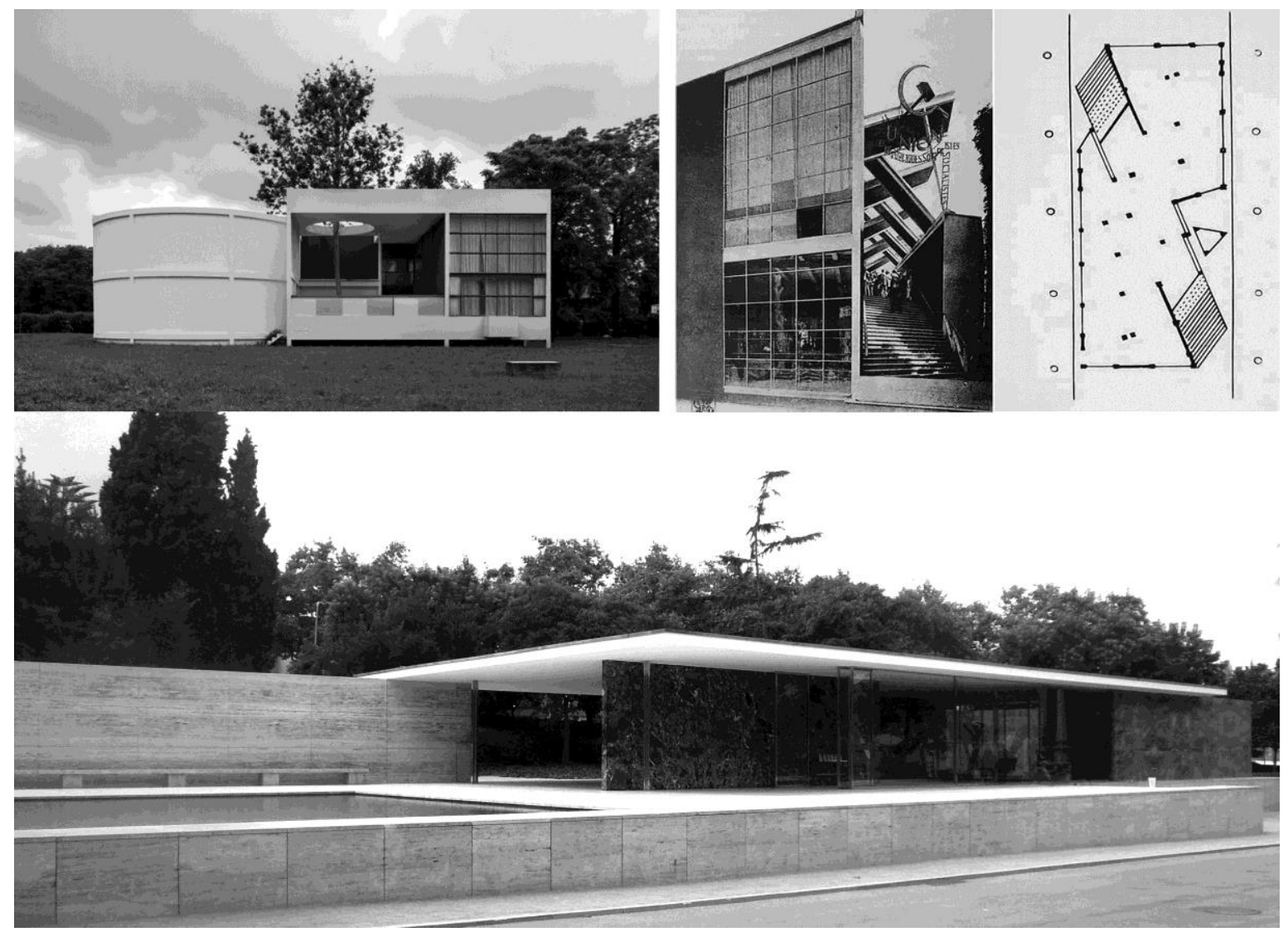

Fig.1. From left to right: (a) Le Corbusier, l'Esprit Nouveau pavilion, International Exhibition of Modern Decorative and Industrial Arts, Paris, 1925 replica, Bologna, 1977; (b) K. Melnikow, USSR Pavilion, International Exhibition of Modern Decorative and Industrial Arts, Paris, 1925; (c) Mies van der Rohe, Barcelona pavilion, 1929. Source: pinterest.com

Fig.1. Od lewej do prawej: (a) Le Corbusier, Pawilon l'Esprit Nouveau, Wytawa Sztuk Dekoracyjnych, Paryż, 1925 replika, Bologna, 1977; (b) K. Mielnikow, Pawilon USSR, Wytawa Sztuk Dekoracyjnych, Paryż, 1925; (c) Mies van der Rohe, PawiIon barceloński, 1929. Żródło: pinterest.com

In the twentieth century, the transformation that took place together with the rise in significance of pavilion architecture denoted a transition from the period of the first inventions, discoveries and compositions - and after one hundred years appears to have been responsible for domesticating Modernist culture and creating secondary or new threads of it. 
During the first phase, functional and technological transformations, prefabrication and mass production were all conducive to the development of architecture and turned it into a sort of manifesto of the creative potential of the architect and structural engineer.

During the second phase (after the Second World War), pavilion architecture defined the development of new ideas and current trends in architecture and though there were pioneering structures by well-known designers, such as Le Corbusier's Philips Pavilion (Brussels, 1958), The Biosphere geodesic dome by Buckminster Fuller, Habitat 67 by Moshe Safdi or the tent-like structures by Frei Otto (Montreal, 1967) they were primarily an establishment of the technological race of the previous decades and innovation - but were also the first proof of Modernism's split into numerous smaller trajectories that were building architectural reality. One can go as far as to say that the idea of Modernism brought not as much the universality of notions like 'international architecture', the 'free plan' or the 'open structure', but it also discovered the phenomenon of the globalisation of World's Fair and Expo pavilion architecture and ultimately questioned the durability of all notions beyond all doubt.

During the third, current period, the phenomenon of the significance of pavilion architecture is continually reinforced as a fashionable idea of producing a new form that exists in a specific timeframe and that creates independent directions of building 'everything by everyone'. Temporariness has become a paradoxical value of building. This also includes the idea of related arts, sculptures, installations or design, and thus creating a packaging for exhibitions planned by a curator. Today we even discuss the 'terror of design', which has slowly began to determine architecture's departure from the subject of a self-offering space comprised of function, structure and form. Architecture, which needs its own description in the permanent physicality of a work and a clear cultural message, creates its own independent expression in pavilion forms without being interested in function, purposefulness and permanence. The independence of such a form can also denote that we acknowledge architecture not only as a building, but that it is something more than the art of building.

The construction of pavilions for the Serpentine Gallery in London's Kensington Garden is an important example. Every year since 2000, each of the invited designers builds their own version of architecture. The park structures, exceptional in their selfless expression, prove that architecture has its own field of existence and assures us that the idea is still a basis of creation that is superior to form. The architecture of the Serpentine Pavilions is like a 'stone cast into the lake', is intended to disrupt natural peace and logic, and 'mobilise space' in a new perception of formal action, whose strength lies in a visual stimulus. They are also a continuous reference to the words of Gio Ponti from 1957, that architecture as an ideative, visual and abstract fact is colourless - it is like a 'mass of crystal' - as every idea is 'naturally transparent'. Architecture that does not need its description in the physicality of a work and in an explicit cultural message, creates its own independent existence and expression in pavilion forms which are not interested in function, purposefulness or permanence. This 'independence of form' can also denote that we finally acknowledge that architecture is not buildings.

We can find an explicit synthesis in the paradox of ephemeral architecture in the rationalist approach by Oswald M. Ungers. He summarised the problem of 'temporary architecture' via a universal argument that states that there are two fundamental types in architecture: the house and the ark. The first type symbolises permanence and immutability. The house is permanent and is tied to the place where it stands. The second type is 'movable' and has a temporary and mutable character. The ark often changes its place and does not have a permanent place of its own - it needs no foundation, as it is not permanent. The house is permanent, the ark denotes evanescence. The house is built of stone, the ark out of acacia wood. The house is a cave and a shelter. The ark is a 'tent' and a makeshift structure. This is why it appears that contemporary nomadic culture better suits tents and successive versions of arks. This impermanence of buildings in light of environmental protection problems is even more suitable and assures us that they should leave no trace of their existence. However, the traces of Modernism and its universally understood international style' continue to remain in the subconscious of both designers and viewers of contemporary temporariness alike. 


\section{TOWARDS ELEMENTARITY, OR A PERMANENCE OF MEANINGS}

In the freedom of design in the twenty-first century, we can still observe a rationalist manner of thinking about architecture. This view is widely known as an empirical outlook on the world that surrounds us and convinces designers that limiting themselves to studying physical phenomena and facts, which can be measured and justified, does not leave them without aesthetic value. Architectural rationalism remains an intellectual concern focused on separate elements and isolated facts derived from direct experience. Thinking is strictly confined to technical and practical processes that are best formulated in theories and methodologies based on practice and experience. Architecture cannot present the universe solely via its form, it must also present it in the essence of rationalising said form. Perfection opens before us a limitless source of representation.

Thinking about pavilion architecture is thus setting an elementary starting point for studying the essence of architecture whose roots reach to the source of all aesthetic rationalism, which assumes not only the potency of geometry, but also its poetic interpretation as aesthetics. Elementary means - base, source, indivisible - the simplest in thinking and creating the fundamental meanings of architecture - via its geometric and material references. We discover it not only in the unique design 'tactic' of many contemporary designers, but also in theories that reference fundamental meanings for contemporaneity - from the proto-Modernist 'primitive shelter' of Abbot Laugier, the 'pre-form' of Louis Kahn, Le Corbusier's purism or the purity of form shown by Tadao Ando. In this set of ideas we can find the book by Raimund Abraham "Elementare Architektur", as well as the work by Bernard Rudofski "Architecture without Architects".

The basis for building elementary meanings is geometry. Geometry that denotes the perfection of form and its continued existence throughout history and culture. Geometry that forces judgement, which is based on reaching an explicit and legible relationship between a concept and its practical realisation on a piece of paper. It appears that creating a consistent repository of knowledge starting with an elementary handbook of architecture terms and ending with an advanced formula of architecture, can be a certain principle that is conveyed using reliable and understandable language. The word elementary also means something that is determined using a consistent and logical process of controlling balance over the poles of architecture - a general and detailed one.

The work of the Chilean duo Pezo von Ellrichshausen, which is on the border between architecture and art, is a fitting example. The practice is known for their fascination with pavilion architecture as a continuous attempt at crossing the line between the art of building form and other visual arts. Their ideas, presented in 2015 at the Chicago Biennale - the Cent Pavilion - or the Bell Pavilion built in Vitry-sur-Seine (2016), continually attest to the fact of searching for the simplest, geometric principle of fleeting quality that, by its formal and material universality, will be understood by every viewer. However, the idea of geometric architecture is to Pezo von Ellrichshausen not as much a reference to the general notion of identity, but also the capacity of a building to be distinctive, singular and unique. The buildings they build are treated as singular structures full of spatial and material value, objects that are defined not only by their internal atmosphere, but also by presence, by personality, by similarity to each other. This approach by the architectural duo appears to speak of a serious focus on 'primal forms'.

The Vara Pavilion, built for the sixteenth Venice Biennale in 2016, is particularly significant for to team. The pavilion is composed of ten round wall elements of varying size, which the architects described as 'a series of external spaces in other external spaces'. This structure, paradoxically simple in its repeatable principle, by creating an arched, 'curved space', each time creates a new impression of the shape of the interior, perspective and relationship between the background or additional visual experiences of the matter of coarse plaster, with the abstract, uncovered space. It is also an awareness of the role of cheap material that the unreal world of ideas and ideals, thoughts and words, concepts and sketches, that transports the art of Pezo von Ellrichshausen into the space of real values, subjected to an ultimate assessment and experience. The application of material in the simplest manner - in a top-bottom fashion - is an idea not as much for finding the relationship between a work's idea and matter, inasmuch as it is a non-impulsive attainment of a simple, and communicative essence of architecture. Following this rule, architecture should be self-describing and introvert, and thus the language used by the building's author is to be a medium 
that is rigorously extracted from logic, simplicity, geometry and numbers - simply from engineering. For as Schelling wrote: 'matter is the absolute truth and the mind is its essence'.(fig.2)

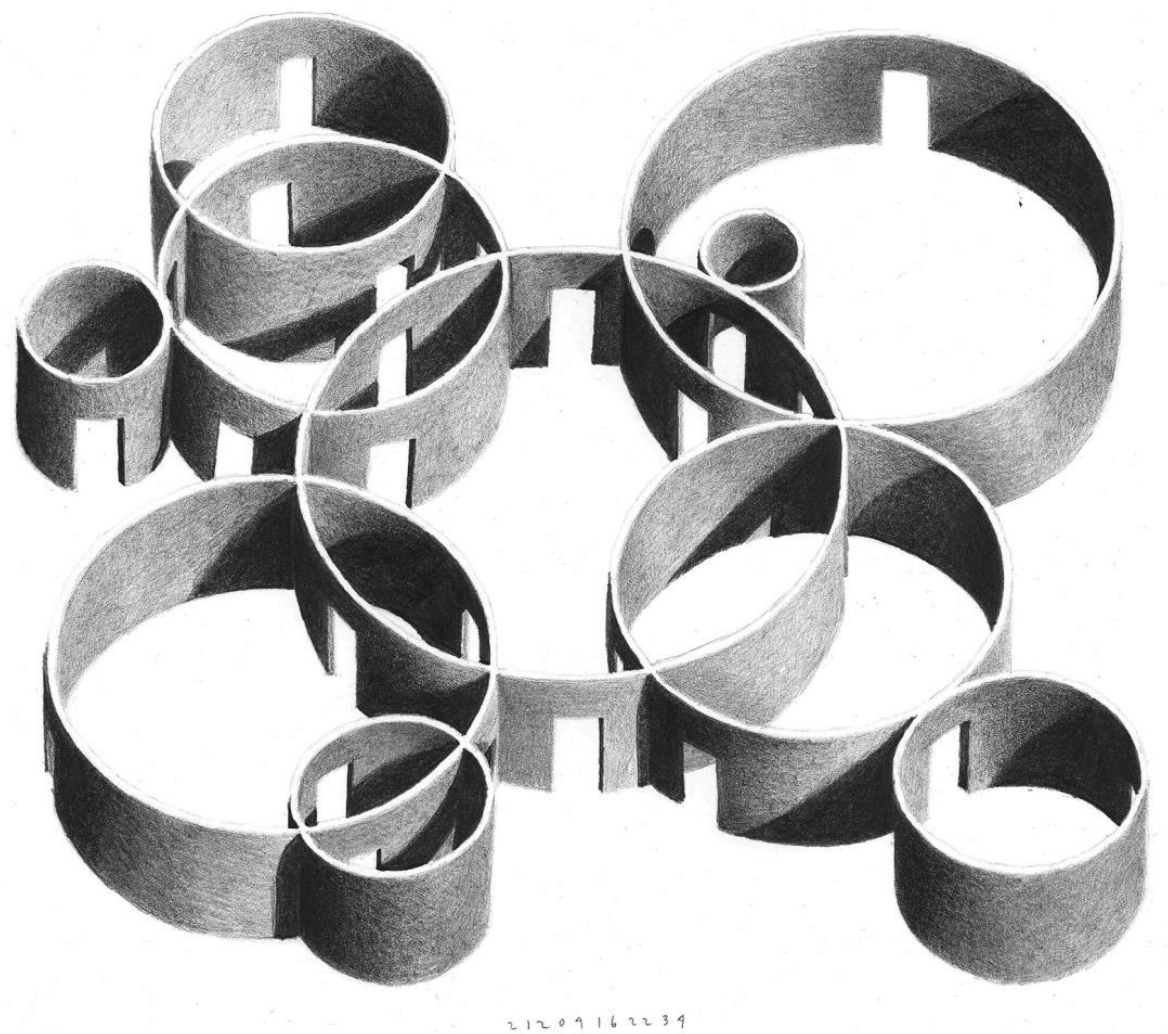

Fig.2. Pezo von Ellrichshausen, Vara Pavilion, axonometric drawing, Venice Architectural Biennale, 2016. Source: pinterest.com

Fig.2. Pezo von Ellrichshausen, Vara Pavilion, rysunek aksonometryczny, Biennale Architektury w Wenecji, 2016; żródło: pinterest.com

This is merely one of many examples in which architectural 'forms without function' are built as proof of the will of architects to indicate a pure, extra-functional aesthetic experience. The practice of sculptors Erwin Heerich and Per Kirkeby, who develop the natural landscape of the Insel Hombroich park (in Neuss near Dusseldorf) with brick objects modelled after the sculptures habitacles André Bloc's 'habitable sculptures', or the Apollo Pavilion (1968) by Victor Pasmore. The park pavilions, 'false' in their utilitarian expression, are a part of the contemporary discourse on the sense of labelling things without utility as architecture. Among the multitude of 'selfless' buildings of Hombroich are Heerich's Turm pavilion (1982), the Tadeusz Pavilion (1992) or the Drei Kapellen (2002), and those by Per Kirkeby, which continually fascinate us with their lack of functional need demonstrating purposeless aesthetics. In addition - the deliberate rejection of utilitas forms a type of timeless monument from these elementary meanings of 'houses', 'aqueducts' or 'labyrinths'. In each of these experimental cases of architecture, there appears a constant asking of questions about the absolute autonomy of architecture and a lack of its connection to a specific function or purpose. The experiences of Raimund Abraham are present in this discussion, as he treats architecture as a 'clash' between the components of architecture's material purity. This confrontationally understood idealisation of form and content is also a reinterpretation of the archetype of architecture. In the monolithic pavilion Musikerhaus (2012), Abraham realised the concept of confronting strictly geometric principles of architecture. 


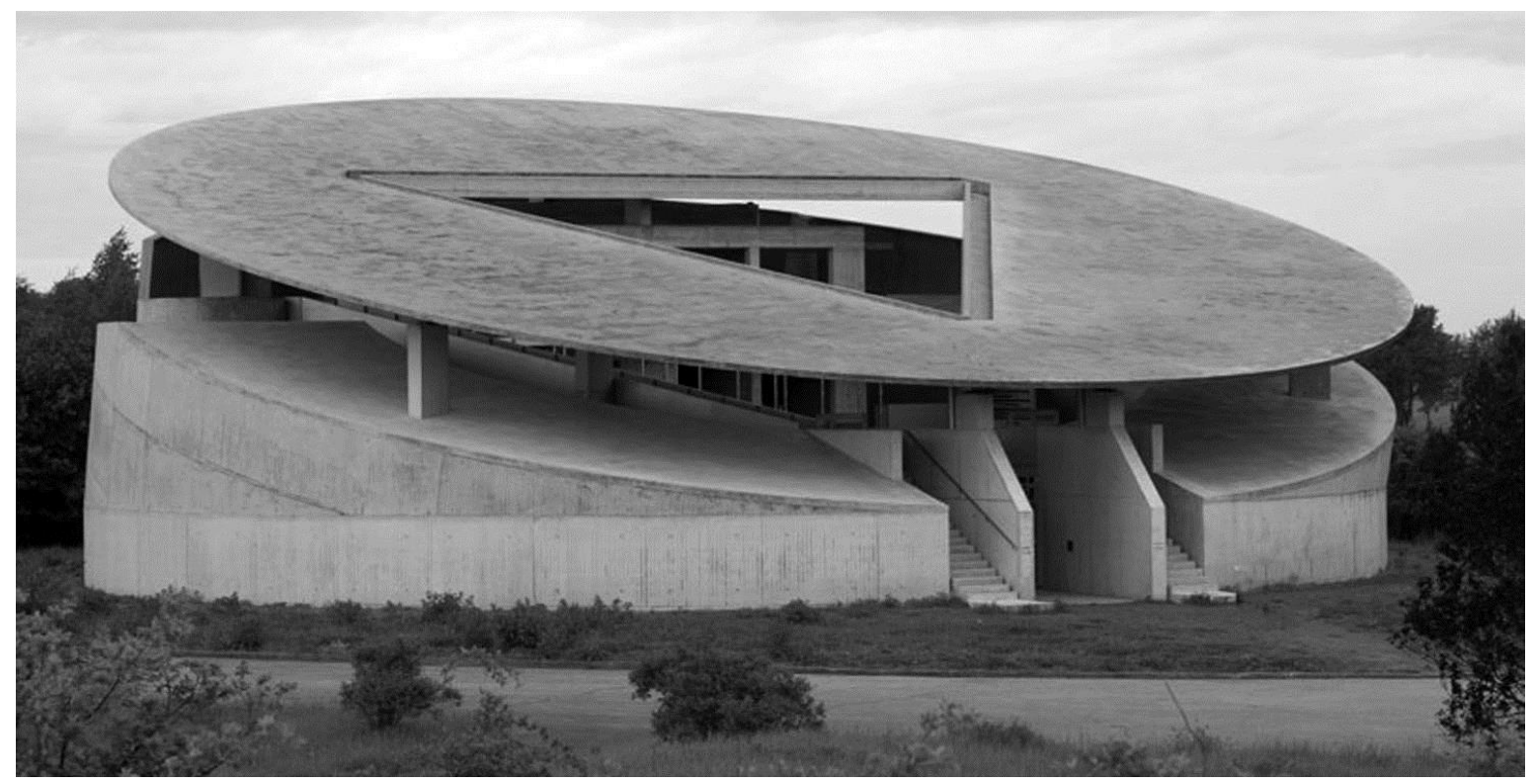

Fig.3. R. Abraham, Musikerhaus, Insel Hombroich, Neuss, 2012; Source: arcspace.com

Fig.3. R. Abraham, Dom dla Muzyka, Insel Hombroich, Neuss, 2012 Źródło: arcspace.com

The composition of a circular mass and a triangular void leads to the choice of only one matter reinforced concrete, a building material that is perfect in its uniformity and clarity, and which is the most permanent in communicating meanings. The ideality of shape, according to the designer, can always be questioned due to the character of the material as every material has its potential, its own emotional power. As the artist notes, the pattern formed on paper must have a precise equivalent in the building, its tectonics and its 'clash' between the ideality of form and the propriety of matter - in order to understand why 'one stone is placed upon another' and how a balance in the formal intensity of elements was reached. Utility in Musikerhaus goes beyond the field of the architect's deliberations on the ideal space of architecture. The geometry of the building on Insel Hombroich likewise remains undisturbed, for in the opinion of the architect it is this geometry which is the language purity, ideal and... concrete permanence (fig.3).

Peter Zumthor's ideative architectural 'patience' can be seen as an equivalent in this context. It is a term of vernacular effort, of the toil of work, in which the aspect of industrial technology is rejected by the architect most clearly. His Hortus Conclusus pavilion for the Serpentine Gallery in London, built in 2011, appears to be a negation against the backdrop of the entire of programmatic formalism - as if the architect claimed that it were even harmful, as it obstructs and clashes with the true values of art, which are always fully material and formal. The idea behind Zumthor's pavilion was a contemplative space, a garden within a garden. The only entrance led to an internal courtyard, isolated from the external world, separated from the noise, traffic and smells of London. This enclosed, rectangular space which reveals the herbarium inside was to be a place facilitating rest, sitting, walking and contemplating a small piece of nature. In the London pavilion, similarly as in his previous projects, Zumthor highlighted the sensory and spiritual aspects of architectural experience. While doing so, he conducts a sophisticated play of composition and the use of the properties of natural materials, their texture and form, masterly operating with scale and light and shadow. In his book Thinking Architecture, Zumthor wrote that architecture has its own area of existence, he did not think that it was 'either a message or a symbol, but as an envelope and background for life which goes on in and around it, a sensitive container for the rhythm of footsteps on the floor, for the concentration of work, for the silence of sleep' . 
In this 'geometric context', the project of a pavilion on the grounds of a penal institution in Tarnów (M. Charciarek, Studio AW, 2002, fig. 4) is significant to the author of the paper. The massing of the single-storey building is a reflection of a certain idea that defines the horizontal and linear figure without a sophisticated narrative, in which function and programmatic guidelines became a pretext for the construction of the simplest play of shapes, unmarred by utility. The forms of the cylinder, tower, cuboid or the fragmentations on the edges of the seventy metres long form - have their meanings only in the structure of the edifice - they demarcate a certain order and principle of creating a 'labyrinth' from the northern (entrance) side and a uniform rhythm of windows on its southern facade.

The building was designed as an answer to the metaphor of a house behind a wall - a world of architecture that is invisible to viewers, whose shape is to correspond to the idea of architecture hidden in forms without openings and perspectives, which performs the function of separation and isolation from the external world. The pavilion, which had been initially intended to be a temporary building, received a logic of a massing limited to the bare formal minimum. The austere reception of the building's structure is to be magnified by the selection of natural facade materials - coloured plaster (venetian pink) and the grey concrete brick of walking courtyards.

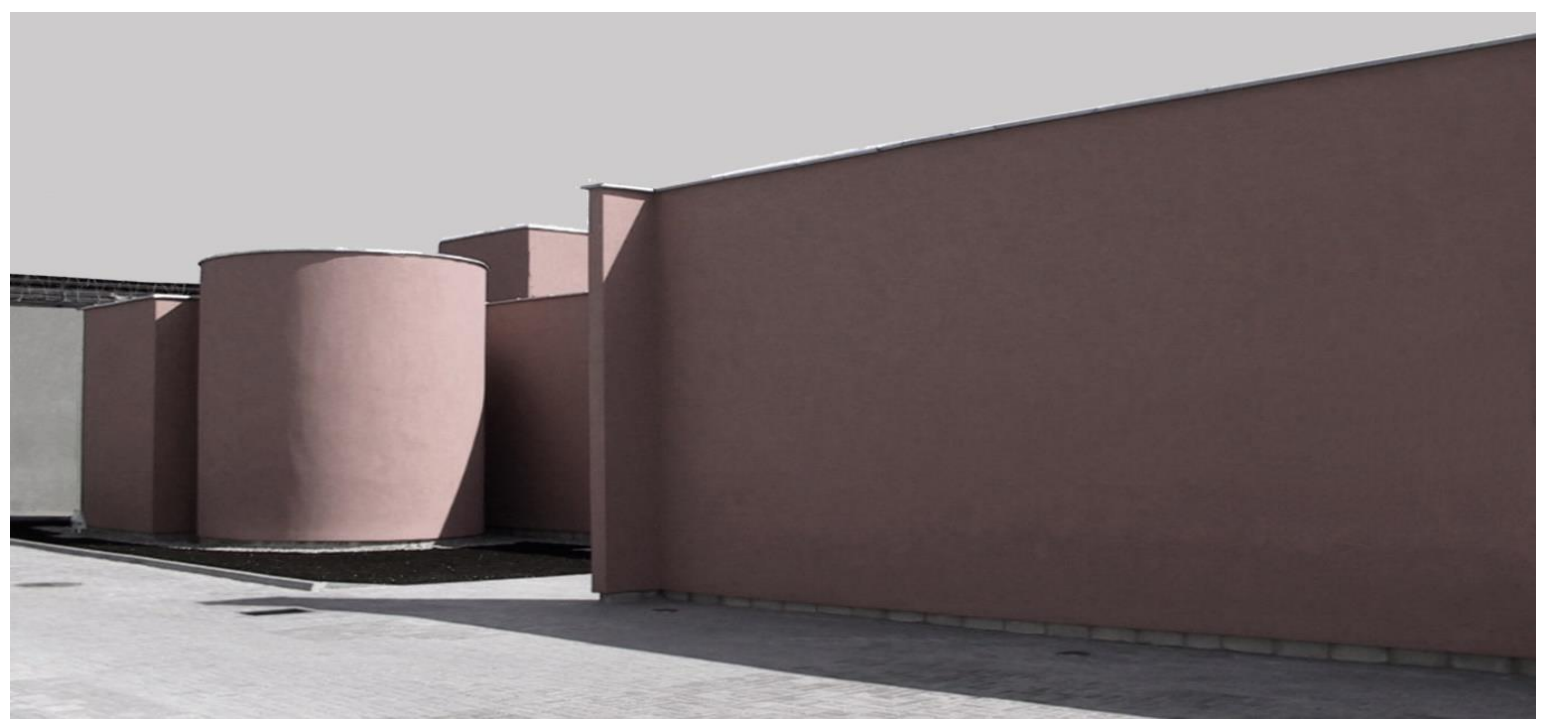

Fig.4. M. Charciarek, Studio AW, Prison pavilion in Tarnów, 2002 source: author photo

Fig.4. M. Charciarek, Studio AW, Pawilon więzienny w Tarnowie, 2002, źródło: fotografia autora

Another consequence of acknowledging pavilion architecture as a model for contemporaneity is the subject for first-cycle first-semester students, entitled Exhibition pavilion in a city park. The design assignment during this introductory learning stage at the Elementary Architecture Department of the Faculty of Architecture of the Cracow University of Technology is based on pursuing and analysing examples of rational contemporary architecture and seeking model architectural spaces within it. The term assignment is based on the preconception that architecture can be sought 'at the centre', 'at the foundations' of architectural space - in an elementary shape. Models of pavilion architecture create a proper research field for all manners of formal pretexts for this uncomplicated architectural form and function. Calling design 'composing' facilitates this - for only in the composition can the layout of combined elements connect into a harmonious and model whole. Light, either imagined on a drawing or set for a working model, plays a significant role in this process. It was therefore determined that the pursuit of individual interpretations of architecture must belong to the discipline of design, and thus a reduction and constraint in form and size - the pavilion should fit 
within a volume that is $8.0 \times 8.0 \times 8.0 \mathrm{~m}$, occupy no more than around $90-100 \mathrm{~m}^{2}$ and have a maximum of two storeys. The pavilion designed by the student is thus to be a figure created from cubic geometry, which can form a basis for answering the questions: what, how, why, in what way and where. The wall, column, window, skylight, stairwell, mezzanine - in every case they play an independent role, demonstrating a new sense of use in architectural space. This intentional 'decomposition' of the building into its 'primary elements' is not as much the most important pretext for the final ideative synthesis, but should also enhance the sense of awareness of the components of architecture (fig.5).

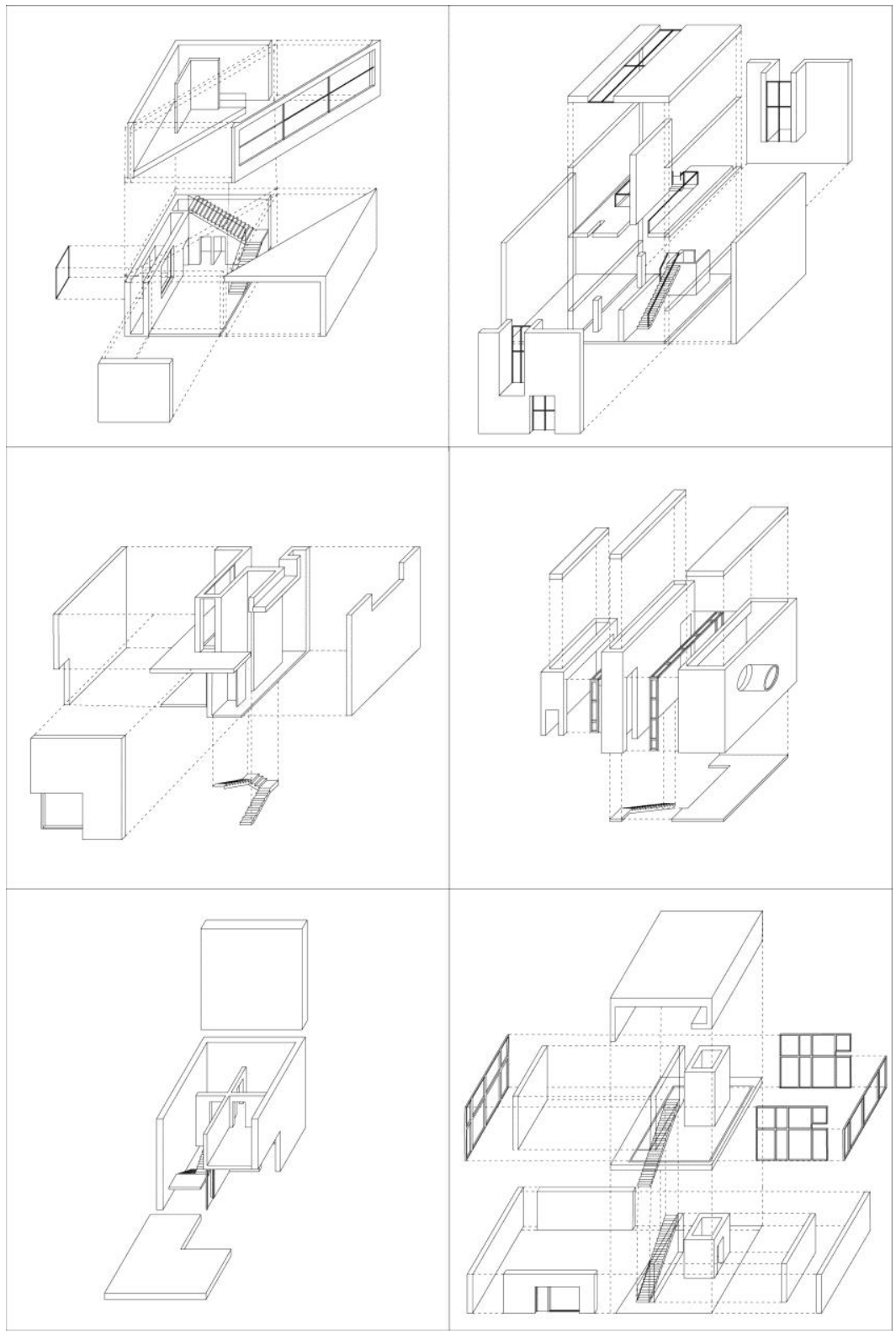

Fig.5. Design assignment for first-cycle first-semester students entitled Exhibition pavilion in a city park, axonometric drawings; from left to right, from top to bottom: stud. W. Boroń, stud. N. Albin, stud. K. Bartula, stud. M. Bizoń, stud. T. Fall, stud. M. Bałazy (2019/2020); CUT FoA Department of Elementary Architecture. Head: dr hab. inż. arch. Marcin Charciarek, Prof. PK

Fig.5. Temat projektowy dla studentów I stopnia 1 roku, 1 semestru pt. Pawilon wystawowy w parku miejskim, Aksonometrie; Od lewej do prawej z góry na dół: stud. W. Boroń, stud. N. Albin, stud. K. Bartula, stud. M. Bizoń, stud. T. Fall, stud. M. Bałazy (2019/2020); Zakład Architektury Elementarnej WA PK. Kierownik: Dr hab. inż. arch. Marcin Charciarek, Prof. PK. 
The architecture of student pavilions is thus a continuous pursuit of originality supported by geometric patterns from the distant and more recent past. It displays a connection to Le Corbusier's purism and his references to 'poetic reaction' caused by 'the learned game, correct and magnificent, of forms assembled in the light'. We can also detect ideas by Mies van der Rohe, to whom solving matters of architectural logic was based on setting a pattern of universal simplicity. The architect always believed that there must a discipline in which answers - a priori - form a single, enclosed, correct architectural system. The key to analogy is not as much 'logical space', as it is the principle of pursuing 'clarity'. References to the works of Louis Kahn are different, as they find 'order' between space and the technology of structure as an inseparable connection and a natural creation of rational beauty.

This first design assignment hides in it another didactic value - firstly, it defines architectures by experiencing all elements of the given architecture; secondly - learning the structure of a building (its form, function and structure) allows one to first understand that architecture is also a means of 'placing stone upon stone'.

\section{CONCLUSIONS}

The phenomenon of pavilion architecture continually confirms the paradigm of contemporary architecture that states that architectural design has become an aesthetically non-uniform art, based on individual references. However, those who believe that it lacks identity and its successive Postmodernist incarnations change as quickly as in a kaleidoscope, are wrong. It turns out that the phenomenon of pavilion architecture continues and still serves as a pattern for references, it is a unique, singular and sole 'aesthetic fact' from which successive generations of designers, teachers and critics have drawn from. Just as in the case of the innovation of single-family houses, the diversity of forms and meanings brought by temporary buildings expands the essence of defining the architecture of the twenty-first century. Temporariness and impermanence of a work does not invalidate its significance, just as ephemeral forms do not cause the disappearance of the idea of architecture and its embodiment.

\section{ARCHITEKTURA PAWILONOWA - WZORZEC CZY EFEMERYDA? W STRONĘ ELEMENTARNOŚCI ZNACZEŃ.}

\section{CEL I METODA}

Celem artykułu jest ukazanie za pomocą wybranych przykładów przeobrażenia pardygmatu trwałości architektury współczesnej jakie dokonało się na przełomie XX i XXI wieku. Z jednej strony przykład architektury pawilonowej stał się wzorcem dla rozumienia znaczeń tymczasowości i i poszukiwania $w$ funkcji pawilonowej bieżących potrzeb i funkcji, $z$ drugiej zaś strony - pawilonowe formy odpowiadają za tworzenie nowych kierunków i idei architektury współczesnej. Bez wątpienia jednym istotnych stylistyk jest ukierunkowanie architektury tymczasowej na pierwotne elementarne odniesienia.

Przyjęto metodę reprezentacji wzorców (z przeszłosci i teraźniejszości) ważnych dla współczesności syntetyzujących problem architektury tymaczasowej.

\section{WSTĘP}

W opisie świata architektury XXI wieku zaprzestano definiowania sensu trwałości i trwania architektury. Ogłasza się wręcz nie tylko o przemijaniu architektury i o jej rezygnacji z trwania, ale też 
o śmierci miejsca i kontekstu - o tym, że wszelkie wysiłki nadawania im znaczeń są daremne. W świecie globalnym przepada jego indywidualny, niepowtarzalny charakter i ginie historyczna warstwa zawartej w nim pamięci. W takiej perspektywie stawianie pytania o trwałość czy przemijalność architektury wydaje się bezprzedmiotowe. Według współczesnych, część architektury w dobie chwiejnej kultury, kryzysów ekonomicznych i zmian klimatycznych, podąża drogą wskazaną przed laty grupę Archigram, pracownię Coop Himmmel(b)au, Buckminstera Fullera - czy współcześnie poprzez wgląd w tekturowe dzieła Shigeru Bana, drewniane konstrukcje Pezo von Ellrichshausen czy paryskie follies Bernarda Tschumiego. Część z twórców uważa, że architektura to ograniczenie do budowania najmniejszych fragmentów naszej biosfery $-z$ czegokolwiek, dla kogokolwiek, gdziekolwiek i bez świadomości na jak długo - chodzi o to aby budynek stał się przykładem zwrotu do najbardziej podstawowego sposobu rozumienia architektury - do jej źródeł elementarnych.

Potwierdza, to także, fenomen kreowania architektury pawilonowej - będącej świadomym manifestem tworzenia rzeczy tymczasowej i alternatywnej (poza pięknem, trwałością i użytecznością), która ma przemówić przede wszystkim oryginalnym (choć krótkotrwałym) rozwiązaniem formy i materii. Użytkowość, w tak potraktowanej „rzeźbie” jest jedynie pretekstem dla stworzenia wyjątkowego efektu architektury - nierzadko bez wspólnej zasady, uznanej reguły, odniesienia do konkretnej teorii. Ten, kto chce mieć dowody na ostateczny rozpad witruwiańskiej triady musi zobaczyć artefakty dorocznego budowania Serpentine Pavillon w Kensington Gardens czy pawilonów wystaw światowych EXPO będących wydarzeniem tak „ulotnym” w swoim istnieniu jak trwała jest wyrazistość indywidualnych aspiracji architektów.

Tymczasowość takiej efemerydy nie oznacza jednak, że zanika idea architektury. Ta trwa, tak długo na ile pozwala pamięć o budowli - na ile zrozumiałe są słowa, myśli i szkice, fragment budulca lub pozostawiony na nim kolor czy faktura. Odbudowany, po latach, barceloński pawilon Ludwika Miesa van der Rohe nie pozostawia wątpliwości, że ostatecznie wartości sztuki (choćby najbardziej kruchej) wykraczają poza jednostkę, poza jej czasy i warunki istnienia. Co potwierdzają słowa Heraklita: Nie ma niczego, wszystko się staje.

Idea architektury pawilonów nakłada się na historię architektury nowoczesnej. Od początku $\mathrm{XX}$ wieku fenomen architektury pawilonowej dał pretekst aby zaczęto mówić o architekturze w kategorii nowości i oryginalności. Nowość miała się realizować poprzez brak jakichkolwiek odniesień, orygnalność poprzez - nieoczywistość formy. Wystawy światowe oznaczają również początek designu a więc projektowania wyglądu czegoś co może być architekturą, mostem, meblem, maszyną. Słowa Hansa Holleina z 1969 roku że wszystko jest architekturą wieńczy niejako całość zjawiska łączącego architekturę ze wszystkim co może nią się stać niezważając na funkcję, nietypową strukturę, niespotykany dla budynku kształt.

Dziś, ceną za takie ustanowienie rzeczy jest jej krótkotrwałość i doczesność. Ten pawilon, który jest bardziej nowatorski lub rozwiązuje aktualne kwestie (formalne, socjalne, strukturalne) staje się rzeczą orygianalną i często pozostaje w historii teraźniejszości architektury jako „rzecz pierwsza”. Nieduży i podążający za istotą rzeczy pawilon w swoim wyrazie i znaczeniu stał się w swojej syntezie tym co jest najważniejsze w aktualnych hasłach współczesności.

Przykład architektury pawilonowej jako rzeczy tymczasowej ale trwającej w czasie ropoczyna historia Wieży Eiffla, która zbudowana jako brama wejściowa na Wystawę Światową w 1889 roku w Paryżu przetrwała i nadal jest symbolem miasta oraz najczęściej odwiedzanym pawilonem na świecie.

\section{TRWAŁOŚĆ WZORCÓW NOWOCZESNOŚCI}

Architektura pawilonowa - począwszy od londyńskiego Crystal Palace Jospha Paxtona (1851) stała się rodzajem manifestu autorskiego, politycznego, ideologicznego pokazującą zawsze nową technologię, kulturę, estetykę. Pawilon niejako staje od tego momentu rodzajem budowy modelu architektonicznego w skali 1:1 - jest narracją bez słów i zapisów ukazującym sedno architektury za pomocą najbardziej wyrazistych środków skondensowanych formalnie. Nierzadko pawilon był 
wstępem dla wielkiej i ważnej twórczości odkrywającej nowe definicje przestrzeni achitektonicznej. Dla modernizmu przełomowa była - w pierwszych abstrakcyjnych poszukiwaniach - Paryska Międzynarodowa Ekspozycja Sztuki Dekoracyjnej w 1925 roku, gdzie po raz pierwszy Le Corbusier zaprezentował idee L'Esprit Nouveau (fig.1a) za pomocą białego purystycznego obiektu. Budowla zawierająca koncept modeleowej przestrzeni mieszkalnej stała się zapowiedzią domu rozplanowanego na „otwartym planie” i realizującego 3 lata później w Poissy i Weissenhof pięć zasad współczesnej architektury. Innym wielkim wydarzeniem tej ekspozycji był pawilon USSR autorstwa Konstantego Mielnikowa (fig.1b), który rozbudził w architekturze Związku Radzieckiego (i poźniej w całej zachodniej Europie) nurt konstruktywizmu z orygianalnym podejściem do zależnosci pomiędzy celowością i estetyką konstrukcji a jej założeniami funkcjonalnymi. Po raz pierwszy ujawniona na zewnątrz struktura pawilonu USSR (w tym przypadku stalowa) odgrywa pierwszoplanową rolę nad użytecznością - tak jak czysty awangardowy formalizm tego dzieła wieszczy wszystko to co się wydarzy w architekturze pomiędzy powojennym brutalizmem a późniejszą dekonstruktywizmem. Ewenement pawilonu Mielnikowa stał się także zapowiedzią przemiany zawodu architekta w poszukiwaniu logicznych, czystych i inżynieryjnych kształtów dla celów stricte fikcyjnych.

Trzecim filarem wzorcowej architektury modernizmu współczesnej jest bez wątpienia niemiecki pawilon w Barcelonie Miesa van der Rohe (fig.1c) wybudowany na Wystawę Światową w 1929 roku. Budynek stanowi demonstrację przyszłego modernistycznego kształtowania przestrzeni, korzystającego z zasady w pełni otwartego niesymetrycznego planu, w którym nie istnieje wyraźny podział na wewnętrzną i zewnętrzną. Po raz pierwszy ściany uwolnione są od funkcji konstrukcyjnej, stanowią jedynie przegrodę poddaną stricte budowaniu kompozycji i są wizulizacją przestrzeni, do którą architekt będzie się odwoływał we wszystkich swoich późniejszych projektach mieszkaniowych i użyteczności publicznej. Barcelońskie dzieło Miesa van der Rohe to także filar przyszłej architektury racjonalizmu i nurtów minimalistycznych. Rekonstrukcja pawilonu w 1986 roku wykonana przez hiszpańskich architektów Cristiana Cirici, Fernando Ramosa i Ignasi de Solà-Moralesa potwierdza fakt trwania idei architektury Miesa van der Rohe i nieodpartą wolę ciągłego udokumentowania jego roli w architekturze współczesnej.

\section{WZORCE KAŻDEJ IDEI}

Architektura efemeryczna istnieje od początku naszej historii. Jednak nigdy nie zwracało to naszej uwagi ani zainteresowania, że może istnieć architektura o mniejszej lub większej trwałości. Nawet mityczny w swoim znaczeniu architektonicznym prymitywny szałas opata Laugiera nie był refleksją nad sensem trwania racjonalnej drewnianej struktury poza jej znaczeniem czysto formalnym i żródłowym. A jednak, kiedy ludzie przeszli z koczowniczego do siedliskowego tryby życia zaczało im zależeć na stabilności i trwałości przestrzeni w której bytują. Od tego momentu domy w osadzie miały zapewnić wygodne miejsce do spędzenia wszystkich pór roku w jednym miejscu. Ich trwałość uniezależniona od natury pozostaje podstawową koncepcją do zrozumienia architektury jako ludzkiej wytwórczości przenoszonej poprzez utrwalenie kultury w określonym systemie. Owa trwałość usystematyzowana kanonami (witruwiańskiej) cywilizacji zachodnioeuropejskiej to także myślenie o architekturze w kategorii dzieła sztuki (artificio) - a więc dziedzictwa i wspólnoty. Nie przewidywała ona rozróżnienia pomiędzy trwałością materii a trwaniem idei - wynikało to z jednoznacznego przeświadczenia, że ciągłość w architekturze dotyczy przede wszystkim wzorców monumentalnej „res privata” (siedzib władzy, obiektów sakralnych, pałaców), odróżnianej od nietrwałej w czasie „res publica” (powszechnej mieszkaniowej czy służącej produkcji). Takie rozumienie architektury miało swoje odzwierciedlenie w zastosowanych budulcach i w podejściu do rozumienia jak należy je wykorzystać znaczeniowo i jaki jest cel ich wykorzystania.

W dwudziestym wieku przemiana jaka dokonała się wraz z nadejściem znaczenia architektury pawilonowej oznaczało przejście przez czas pierwszych wynalazków, odkryć i kompozycji - i po stu latach wydaje się odpowiedzialna za oswojenie kultury modernistycznej i stworzenie jej wtórnych lub nowych wątków. 
W pierwszej fazie sprzyjające rozwojowi architektury przemiany funkcjonalne, technologiczne, prefabrykacja, masowa produkcja spowodowały, że architektura stała się niejako manifestem możliwości twórczych architekta i konstuktora.

W drugiej fazie (po II wojnie światowej) architektura pawilonowa ustanowiła rozwój nowych idei oraz bieżących trendów architektury i choć pojawiały się pionierskie konstrukcje znanych twórców, jak pawilon Philipsa Le Corbusiera (Bruksela 1958r.), amerykańska kopuła geodezyjna Richarda Buckministera Fullera Biosfera, Habitiat 67 Moshe Safdiego czy namiotowe konstrukcje Otto Frei'a (Montreal 1967r.) to były one przede wszystkim ustanowieniem trwającego w przeszłych dziesięcioleciach wyścigu technologicznego i nowatorstwa - ale także pierwszym dowodem na rozbicie modernistycznego kierunku na wiele wątków budujących rzeczywistość architektoniczną. Właściwie można by rzec, że idea modernizmu przyniosła nie tyle uniwersalność takich pojęć jak „architektura międzynarodowa”, „wolny plan” czy „otwarta struktura” lecz także odkryła fenomen globalizacji architektury pawilonów Targów Światowych oraz EXPO i poddała ostatecznie ponad wszelką wątpliwość trwałość wszelkich pojęć.

W trzecim, obecnym okresie fenomen znaczenia architektury pawilonowej jest wciaż utrwalany jako modna idea wytwarzania nowej formy ale trwającej w określonym przedziale czasowym i tworzącej niezależne kierunki budowania „wszystkiego przez wszystkich”. Tymczasowość stała się paradoksalną wartością budowania. Zawiera się w tym także idea sztuk pokrewnych, rzeźb, instalacji, designu, a więc stworzenia opakowania dla ekspozycji wymyślonej przez kuratora... Dziś, mówi się wręcz o „terrorze designu” powoli przesądzającym o tym, że architektura odchodzi od tematu semoreferującej się przestrzeni złożonej z funkcji, konstrukcji i formy. Architektura, która nie potrzebuje swojego opisania w trwałej fizyczności dzieła i jednoznacznym przekazie kulturowym tworzy swój niezależny wyraz w pawilonowych formach bez zainteresowania funkcją, celowością, stałością. Samodzielność takiej formy może także oznaczać, że uznajemy architekture nie tylko za budynek...że jest czymś ponad sztukę budowania.

Ważnym przykładem tego rodzaju myślenia jest doroczne wydarzenie jakim jest budowa pawilonu dla Serpetine Gallery w londyńskim parku Kensigton Garden. Co roku - od 2000 roku - każdy z zaproszonych twórców realizuje swoją wersję architektury. Wyjątkowe w swoim bezinteresownym przekazie parkowe budowle co roku udowadniają, że architektura ma swój własny obszar istnienia i zapewniają, że idea dla formy jest wciąż nadrzędną bazą kreacji. Architektura Serpetine Pavilion jest jak „kamień wrzucony do stawu”, który ma burzyć strukturalny spokój i logikę, ma „mobilizować przestrzeń" w nowym postrzeganiu akcji formalnej, których siła tkwi w wizualnym bodźcu. I są ciągłym nawiązaniem do słów Gio Pontiego z 1957 roku, że architektura jako ideowy, plastyczny i abstrakcyjny fakt jest bezbarwna - jest jak „bryła kryształu” - pionieważ każda idea jest „naturalnie przezroczysta". Architektura, która nie potrzebuje swojego opisania w fizyczności dzieła i jednoznacznym przekazie kulturowym tworzy swój niezależny byt i wyraz właśnie w pawilonowych formach niezainteresowanych funkcją, celowością, stałością. Taka „samodzielność formy” może także oznaczać, że nareszcie uznajemy, że „architektura to nie jest budynek”.

Jednoznacznej syntezy w paradoksie efemerycznej architektura dopatrujemy także się w racjonalistycznym podejściu Oswalda M. Ungersa. Problem „tymczasowej architektury” architekt podsumowuje uniwersalaną tezą mówiącą o tym, że $w$ architekturze istnieją dwa podstawowe typy: dom i arka. Pierwszy typ symbolizuje niezmienność i stałość. Dom jest trwały i jest związany z miejscem w którym stoi. Drugi typ jest „ruchomy”, ma charakter czasowy i zmienny. Arka zmienia często swoje miejsce i nie ma stałego punktu postoju - nie potrzebuje fundamentu, ponieważ nie jest trwała. Dom to trwałość, arka oznacza przemijanie. Dom jest zbudowany z kamienia, arka z drzewa akacjowego. Dom jest jakinią i osłoną. Arka jest „namiotem” i prowizorycznością. Dlatego wydaje się, że współczesna kultura nomadyczna jest bardziej odpowiednia dla namiotów i kolejnych wersji ark. Ów brak trwania budowli wobec problemów ochrony środowiska jest wręcz stosowniejsze i daje pewność na nie pozostawienie po sobie śladu. Jednak ślad po modernizmie i po jego uniwersalnie zrozumiałym "miedzynarodowym stylu” pozostaje nadal w podświadomosci tak twórców jak i widzów współczesnej tymczasowości. 


\section{W STRONĘ ELEMENTARNOŚCI, ALBO KU TRWAŁOŚCI ZNACZEŃ}

Pomiędzy dowolnością tworzenia w XXI wieku widoczny jest nadal racjonalistyczny sposób myślenia o architekturze. Ów pogląd powszechnie znany jako empiryczny ogląd otaczającego nas świata dostarcza twórcom przekonania, że ograniczenie się do studiowania zjawisk fizycznych i faktów, które mogą być zmierzone i uzasadnione nie pozbawia ich waloró estetycznych . Racjonalizm architektoniczny jest nadal intelektualną troską skupiającą się na oddzielnych elementach i wyizolowanych faktach, pochodzących z bezpośredniego doświadczenia. Myślenie jest ściśle ograniczone do technicznych i praktycznych procesów, które są najlepiej sformułowane w teoriach i metodologiach opartych na praktyce i doświadczeniu. Architektura nie może przedstawiać uniwersum tylko za pośrednictwem formy, musi je przedstawiać zarazem w istocie racjonalizacji formy. Doskonałość i perfekcja odkrywa przed nami nieograniczone źródło reprezentacji.

Myślenie o architekturze pawilonów jest zatem ustanowieniem elementarnego punktu wyjścia dla badania istoty architektury, której korzenie sięgają źródeł wszelakiego racjonalizmu estetycznego przyjmującego za estetykę nie tylko potencję geometrii lecz także jej interpretację poetycką. Elementarne to znaczy - bazowe, źródłowe, niepodzielne - najprostsze w myśleniu i kreowaniu znaczeń podstawowych architektury - poprzez jej geometryczne i materialne odniesienia. Odkrywamy go nie tylko w swoistej „taktyce” projektowej wielu współczesnych autorów lecz także w teoriach odnoszących się do znaczeń fundamentalnych dla współczesności - od proto-modernistycznego „prymitywnego szałasu” opata Laugiera, „pra-formy” Louisa Kahna, puryzmu Le Corbusiera czy czystości form Tadao Anda. Można odnaleźć w tym zbiorze idei książkę Raimunda Abrahama „Elementare Architektur"” jak i dzieło Bernarda Rudofskiego „Architecture without Architects”.

Podstawą budowy elementarnych znaczeń jest geometria. Geometria - oznaczająca doskonałość formy i jej trwanie w historii architektury i kultury. Geometria - wymuszająca osąd, który polega na dochodzeniu do jednoznacznej i czytelnej relacji pomiędzy konceptem a jego praktyczną realizacją na kartce papieru. Wydaje się, że tworzenie konsekwentnego zasobu wiedzy - począwszy od elementarza terminów architektury aż do zaawansowanej formuły architektonicznej może być pewną zasadą przekazywaną językiem wiarygodnym i zrozumiałym. Elementarne to znaczy także wyznaczone konsekwentnym i logicznym procesem kontrolowania równowagi nad biegunami architektury - ogólnym i szczegółowym.

Właściwym przykładem jest twórczość chilijskiego duetu Pezo von Ellrichshausen odnajdujacych się na granicy architektury i sztuki. Zespół znany jest z ze swojej fascynacji architekturą pawilonową jako ciągłej próby przekraczania granicy pomiędzy sztuką budowania formy a innymi sztukami wizualnymi. Ich pomysły prezentowane w 2015 roku dla chicagowskiego biennale - Cent Pavilion czy w wybudowanym Bell Pavilion (2016) w Vitry-sur-Seine cały czas dowodzą na poszukiwanie najprosztej, geometrycznej zasady nieuchwytnej jakości, która poprzez swoją uniwersalność formalną i materiałową będzie zrozumiała przez każdego widza. Jednak idea geometrycznej architektury jest dla Pezo von Ellrichshausen nie tyle odniesieniem ogólnego pojęcie tożsamości lecz także zdolnością budynku do bycia charakterystycznym, pojedyńczym i niepowtarzalnym. Budynki przez nich stawiane traktowane są jako pojedyncze obiekty pełne walorów o charakterze przestrzennym i materialnym; przedmioty, które są określone nie tylko przez wewnętrzną atmosferę, ale także przez obecność, przez osobowość, podobieństwo do siebie. Takie podejście dwójki architektów wydaje się mówić o poważnym zaabsorbowaniu „formami pierwotnymi”.

Szczególnie ważny dla zespołu jest Vara Pavilion skonstruowany na XVI Biennale w Wenecji w 2016 roku. Pawilon ten składa się z dziesięciu różnej wielkości okrągłych elementów ściennych, które architekci opisali jako „szereg przestrzeni zewnętrznych w innych przestrzeniach zewnętrznych" (fig.2). Ta paradoksalnie prosta w swojej powtarzalnej zasadzie budowla, poprzez wytworzenie łukowatej, „zakrzywionej przestrzeni”, wytwarza za każdym razem nowe odczucie kształtu wnętrza, perspektywę, relacje z tłem czy kolejne wizualne odczucia materii chropawego tynku z abstrakcyjnym przestrzeni bez przykrycia. To także dzięki świadomości roli taniego materiału nierealny świat idei i ideałów, myśli i słów, koncepcji i szkiców przenosi sztukę Pezo von Ellrichshausen w przestrzeń realnych wartości, podlegających ostatecznej ocenie i odczuciu. Wykorzystanie budulca w najprostszy sposób - od ogółu aż do detalu - jest pomysłem nie tyle na odszukiwanie relacji pomiedzy ideą a materią dzieła, co raczej jest nie-impulsywnym dochodzeniem do prostej i ko- 
munikatywnej esencji architektury. Zgodnie z tą regułą architektura powinna być samoopisująca i introwertyczna, a więc język, jakim się posługuje autor budowli, ma być medium rygorystycznie wyodrębnionym z logiki, prostoty, geometrii i liczb - po prostu z techniki. Bo przecież jak pisał Schelling: to materia jest absolutną prawdą a jej istotą jest rozumu.

To tylko jeden zwielu przykładów, w których architektoniczne „formy bez funkcji” powstają jako dowód na wolę architektów wskazania czystego, pozafunkcjonalnego doświadczenia estetycznego. Przykładem może być praktyka rzeźbiarzy Erwina Heericha i Pera Kirkeby, którzy w parku Insel Hombroich (w Neuss w pobliżu Düsseldorfu) zabudowują naturalny krajobraz ceglanymi obiektami na wzór sculpture habitacle - „mieszkalnych rzeźb” André Bloca czy Apollo Pavilion (1969) Victora Pasmore’a. „Fałszywe” w swojej wymowie użytkowej parkowe pawilony są tu częścią współczesnego dyskursu dotyczącego sensu nazywania architekturą rzeczy pozbawionych użyteczności. Pośród wielości „bezinteresownych” budowli Hombroich są pawilony Heericha - Turm (1982), Tadeusz Pavilion (1992) czy Drei Kapellen (2002) i Pera Kirkeby, które wciąż fascynują brakiem potrzeby funkcjonalnej - ukazując bezcelową estetykę. Dodatkowo - świadome odrzucenie utilitas tworzy z tych elementarnych znaczeń „domów”, „akwedyktów” czy „labiryntów” rodzaj monumentów o znaczeniu ponadczasowym. W każdym z tych eksperymentalnych przypadków architektury wydaje się ciągłe stawianie pytań o absolutną autonomię architektury i braku jej powiązania $z$ konkretną funkcją czy przeznaczeniem. Obecne w powyższych rozważaniach są doświadczenia Raimundu Abrahama, który traktuje architekturę jako „kolizję” między składowymi materialnej czystości architektury. Tak konfrontacyjnie pojęta idealizacja formy i treści jest także reinterpretacją archetypu architektury. W monolitycznym pawilonie Domu dla Muzyka (2012) Abraham zrealizował koncept konfrontacji stricte geometrycznych zasad architektury. Kompozycja kolistej bryły i trójkątnej pustki prowadzi do wyboru tylko jednej materii budowli - żelbetu, budulca doskonałego w swojej jednorodności i klarowności oraz najtrwalszego w przekazywaniu sensów. Idealność kształtu, według twórcy, może być zawsze zakwestionowana ze względu na charakter materiału, ponieważ każdy materiał ma swój potencjał, własną siłę emocjonalną. Jak uważa artysta wzorzec stworzony na papierze musi mieć precyzyjny odpowiednik w budowli, jej tektonice i jej „zderzeniu” między idealnością formy a stosownością materii - po to, aby zrozumieć, dlaczego „jeden kamień jest postawiony na drugim" i w jaki sposób osiągnięto równowagę w natężeniu formalnym elementów. Użytkowość w Domu dla Muzyka wykracza poza obszar rozmyślań architekta o idealnej przestrzeni architektury. Niezakłócona pozostaje także geometria obiektu na Insel Hombroich, bo to ona jest, w opinii architekta, językiem czystości, ideału i ... betonowej trwałości.

Tożsama w tym kontekście jest ideowa architektoniczna „cierpliwość” Petera Zumthora, będąca określeniem wernakularnego wysiłku, mozołu pracy, w której aspekt technologii przemysłowej jest odrzucany przez architekta nadzwyczaj wyraźnie. Jego pawilon Hortus conclusus dla Serpetine Gallery w Londynie wybudowany w 2011 roku - wydaje się na tle całego programowego formalizmu programową negacją, jakoby sztuce nie była potrzebna ekspresja - jakby architekt twierdził, że jest wręcz szkodliwa, ponieważ przeszkadza i koliduje z prawdziwymi wartościami sztuki, które są zawsze w pełni materiałowo-formalne. Ideą pawilonu Zumthora jest kontemplacyjna przestrzeń, ogród w ogrodzie. Jedyne wejście prowadzi na wewnętrzny dziedziniec, wyabstrahowany ze świata zewnętrznego, odcięty od hałasu, ruchu ulicznego i zapachów Londynu. Ta zamknięta, prostokątna przestrzeń ujawniająca zaprojektowane herbarium ma być miejscem sprzyjającym odpoczynkowi, siedzeniu, spacerowaniu i kontemplowaniu skrawka przyrody. W londyńskim pawilonie, podobnie jak w swoich poprzednich realizacjach, Zumthor podkreśla sensoryczne i duchowe aspekty architektonicznego doświadczenia. Prowadzi przy tym wyrafinowaną grę kompozycji i wykorzystania właściwości naturalnych materiałów, ich faktury i formy, mistrzowsko operując skalą i światłocieniem. W książce pt. „Myślenie Architekturą” Zumthor napisał, że architektura ma swój własny obszar istnienia - nie jest ona „zasadniczo przesłaniem, ani znakiem, lecz oprawą i tłem dla przemijającego życia, wrażliwym naczyniem dla rytmu kroków po podłodze, dla skupienia przy pracy, dla ciszy snu".

W tym "geometrycznym kontekście" ważną dla autora artykułu wydaje się realizacja pawilonu na terenie zakładu karnego w Tarnowie (M. Charciarek, Studio AW, 2002, fig. 4). Bryła parterowego budynku jest odzwierciedleniem pewnej idei wyznaczającej horyzontalną-liniową figurę bez wyszukanej narracji, dla której funkcja i wytyczne programowe stały pretekstem dla powstania niezmąco- 
nej użytkowością najprostszej gry kształtów. Formy walca, wieży, prostopadłościanu czy rozczłonkowania na krańcach 70-metrowej formy - mają swoje znaczenia tylko w strukturze budowli oznaczają pewien porządek i zasadę stworzenia „labiryntu” od strony północnej (wejściowej) oraz jednorodnego rytmu okien w elewacji południowej.

Obiekt został zaprojektowany jako odpowiedź dla metafory domu za murem - świata architektury niewidocznego dla widzów, którego kształt ma odpowiadać idei architektury ukrytej w formach pozbawionych otwarć i perspektyw, realizującej funkcję separacji i oddzielenia od świata zewnętrznego. Pawilon, który w zamyśle miał być obiektem tymczasowym uzyskał logikę kubatury ograniczonej do niezbędnego minimum formalnego. Surowy odbiór struktury budynku ma potęgować dobór naturalnych materiałów elewacyjnych - barwionego tynku (venetian pink) i szarej cegły betonowej pól spacerowych.

Inną konsekwencją uznania architektury pawilonowej za wzorcową dla współczesności jest temat dla studentów 1 stopnia 1 roku 1 semestru pt. Pawilon ekspozycyjny w parku miejskim. Praca projektowa na tym wstępnym etapie nauki w Zakładzie Architektury Elementarnej na Wydziale Architektury Politechniki Krakowskiej oparta jest na poszukiwaniu oraz analizowaniu przykładów racjonalnej achitektury współczesnej i poszukiwaniu w niej modelowych przestrzeni architektonicznej. Ćwiczenie semestralne - opiera się na przeświadczeniu, że architektury można szukać „w centrum”, „u podstaw” przestrzeni architektonicznej - w kształcie elementarnym. Wzorce architektury pawilonowej tworzą odpowiedni obszar badawczy dla wszelakich pretekstów formalnych tej nieskomplikowanej formy i funkcji architektonicznej. Służy temu nazywanie projektownia komponowaniem - bo tylko w kompozycji układ elementów zestawionych ze sobą łaczy się w taki sposób, aby tworzyły one harmonijną i wzorcową całość. Niebagatelną rolę w tym procesie odgrywa wyobrażone na rysunku lub ustalone światło w makiecie roboczej. Ustalono zatem że poszukiwania własnej interpretacji architektury musi należeć do dyscypliny projektowej, a więc ograniczenia i redukcji w formie i wielkości - pawilon pownienien mieścić się w kubaturze 8,0x8,0x8,0 metrów i zawierać nie więcej niż ok. 90-100m2 na maksymalnie 2 kondygnacjach. Pawilon tworzony przez studenta ma być więc figurą stworzoną z geometrii kubicznej, która może stać podstawą określania odpowiedzi na pytania: co?, jak?, dlaczego?, w jaki sposób?, gdzie?. Ściana, słup, okno, świetlik, klatka schodowa, antresola - w każdym przypadku grają niezależną rolę ukazującą nowy sens wykorzystania w przestrzeni architektonicznej. Ten intencjonalny „rozkład” budynku na „czynniki pierwsze” jest nie tyle najważniejszym pretekstem dla końcowej ideowej syntezy lecz także pownienien utrwalać sens świadomości składowych architektury (fig.5).

Architektura studenckich pawilonów jest zatem ciągłym poszukiwaniem oryginalności wspieranej geometrycznymi wzorcami z odległej i bliższej przeszłości. Widać w niej powinowactwa z puryzmem Le Corbusiera i jego odwołania do „poetyckiej reakcji” wywałanej przez poprawną, mądrą i wspaniałą grę brył w świetle. Dostrzegamy także idee Miesa van der Rohe, dla którego rozwiązania zagadnień logiki architektury polegało, na ustanowieniu wzorca uniwersalnej prostoty. Architekt zawsze uznawał, że musi istnieć taka dziedzina, w której odpowiedzi - a priori - układają się w jeden zamknięty, prawidłowy system architektoniczny. Kluczem do analogii jest nie tyle termin „logiczna przestrzeń” co zasada poszukiwania „jasności”. Odmienne są nawiązania do dzieł Louisa Kahna odnajdujące „ład” między przestrzenią i technologią struktury jako nierozerwalnego połączenia i naturalnego tworzenia racjonalnego piękna.

Ten pierwszy temat projektowy ukrywa w sobie dodatkową wartość dydaktyczną - po pierwsze definiuje architektury poprzez poznanie wszystkich elementów tej architektury; po drugie - poznanie struktury budynku (jego formy, funkcji i konstrukcji) pozwala zrozumieć po raz pierwszy, że architektura, to także jest sposób ułożenia kamienia na kamieniu.

\section{WNIOSKI}

Fenomen architektury pawilonowej wciąż potwierdza paradygmat współczesnej architektury, mówiącej o tym, że twórczość architektoniczna stała się sztuką niejednorodną estetycznie, opartą na indywidualnych odniesieniach. Nie mają racji jednak ci, którzy uważają, że wyróżnia się ona brakiem tożsamości, a jej kolejne, pomodernistyczne wcielenia zmieniają się tak szybko jak obrazy 
w kalejdoskopie. Okazuje się, że fenomen architektury pawilonowej trwa i nadal służy za wzorzec odniesień, jest osobliwym, jednostkowym i niepowtarzalnym „faktem estetyczny” z którego czerpią kolejne pokolenia twórców, dydaktyków, krytyków. Podobnie jak w przypadku nowatorstwa domów jednorodzinnych, różnorodność form i znaczeń jakie przynoszę tymczasowe budowle rozszerza istotę definiowania architektury w XXI wieku. Tymczasowość i nietrwałość dzieła nie unieważnia jego znaczenia tak jak efemeryczne formy nie powodują, że zanika istota idei architektury i jej ucieleśnienie.

\section{BIBLIOGRAPHY}

Abraham R., Counter-Thoughts [in:] Ungebaut/Unbuilt, Innsbruck 1987.

Ellrichshausen Pezo, Naïve Intention, Chicago, 2018.

Folder A-23. Dydaktyka Zespołu Architektury Elementarnej A-23 (pod red. M. Charciarka), Kraków 2020.

Jodidio. Ph, Architecture Now! Temporary, Cologne, 2011.

Ponti G., Amate l'archietttura [in:] "l'Architettura e un cristallo”, Genova 1957.

Ungers O. M. , Steinarchitektur, "Baumeister" no.11'1985 [in:] S. Scholz, Od kolebki architektury aż do obecnego absolutnego designu albo dokąd prowadzi nas ta podróż...? Quo vadis architekturo!, Materiały konferencji "Definiowanie przestrzeni architektonicznej - Trwanie i przemijanie architektury", vol. 1, Kraków 2011.

Schielling J.W., Fiozofia sztuki, Warszawa 1983.

Zumthor P., Myślenie architekturą, Kraków 2010.

\section{AUTHOR'S NOTE}

Head of the Elementary Architecture Team at the Department of Architectural Design A-6, Faculty of Architecture, Cracow University of Technology. Affiliation of SARP O / Kraków, MPOIA. Author of 53 scientific articles in Polish and English. PhD thesis - "About metaphor in contemporary architecture" in 2001. Habilitation thesis entitled "Relationships of ideas and matter in concrete architecture" in 2015. Winner of the Grand Prix Biennale of Architecture 2004. Author of the study "Details of concrete architecture. Polish Architecture 2008-2018 ". A longtime promoter of elementary architecture and concrete architecture.

\section{O AUTORZE}

Kierownik Zespołu Architektury Elementarnej w Katedrze Projektowania Architektonicznego A-6 Wydział Architektury Politechniki Krakowskiej. Przynalezność SARP O/ Kraków, MPOIA. Autor 53 artykułów naukowych w jezyku polskim i angielskim. Doktorat pt. „O metaforze w architekturze współczesnej” w 2001 roku. Praca habilitacyjna pt. „Związki idei i materii w architekturze betonowej” w 2015 roku. Laureat Grand Prix Biennale Architektury 2004 roku. Autor opracowania „Detale architektury betonowej. Architektura polska 2008-2018". Wieloletni propagator architektury elementarnej oraz architektury betonowej.

Contact | Kontakt: marcinch@pk.edu.pl 